\title{
Factors Related to the Presence of Anemia in Patients with Chronic Kidney Disease in Hemodialysis
}

\author{
Lizardi Gómez LF ${ }^{1}$, Reyes Sánchez I', Guerrero \\ Soto J ${ }^{1}$, Rivera Antolin J E ${ }^{1}$, Muñoz Menjivar C ${ }^{1}$, \\ Venegas Vera AV ${ }^{1}$, Camarillo Rosas $C^{2}$, Patiño \\ Ortega $R^{3}$, Arenas Osuna J ${ }^{4}$, Paniagua Sierra $R^{5}$ \\ and Hernández Rivera J $\mathrm{CH}^{5 *}$ \\ ${ }^{1}$ Nephrology Service, Hospital de Especialidades, Centro \\ Médico Nacional La Raza, Mexico \\ ${ }^{2}$ Medical Director, Hospital General de Zona No. 27, \\ Mexico \\ ${ }^{3}$ Medical Director, Centro de Diagnóstico Ángeles \\ (CEDIASA) Guadalupe. Mexico City, Mexico \\ ${ }^{4}$ Health Education and Research Department, Specialties \\ Hospital, "La Raza” National Medical Center, Mexican \\ Institute of Sovial Security (IMSS), México \\ ${ }^{5}$ Medical Investigation Unit in Nephologic Diseases, \\ Hospital de Especialidades, Centro Médico Nacional Siglo \\ XXI, IMSS, Mexico \\ *Corresponding author: J uan Carlos H Hernández \\ Rivera, Medical Investigation Unit in Nephologic \\ Diseases, UMAE Hospital de Especialidades Bernardo \\ Sepúlveda Gutiérrez, Centro Médico Nacional Siglo XXI. \\ IMSS, Av. Cuauhtémoc 330, Col. Doctores, Mexico City, \\ Mexico
}

Received: December 30, 2020; Accepted: February 03, 2021; Published: February 10, 2021 2021; Published: February 10, 2021

\begin{abstract}
Introduction: The prevalence of anemia in Chronic Kidney Disease (CKD) is high. However, little is known about the factors related to anemia in patients with chronic Hemodialysis (HD) in Mexico.

Material and Methods: A cross-sectional study was conducted in adult patients with CKD undergoing HD in the northern area of Mexico City treated at the Mexican Institute of Social Security. Hemoglobin $(\mathrm{Hb})$ and Hematocrit $(\mathrm{Htc})$ levels, as well as clinical and biochemical factors associated with anemia, were evaluated.

Results: Data was collected from 747 patients, obtaining a mean hemoglobin of $9.7 \mathrm{~g} / \mathrm{dl}$ (IQR 8.4-10.9 g/dl). The group was divided into two using $\mathrm{Hb}<10.0 \mathrm{~g} / \mathrm{dl}$ and $>10.0 \mathrm{~g} / \mathrm{dl}$ as cutoff limits. Fifty six percent of the patients had hemoglobin $\leq 10.0 \mathrm{~g} / \mathrm{dl}$. Hb level $<10.0 \mathrm{~g} / \mathrm{dl}$ were associated with DM (OR 1.49, IC 95\% 1.06-2.10, $\mathrm{p}=0.001$ ), hyperphosphatemia (OR 1.69, IC $95 \%$ 1.21-2.28, $\mathrm{p}=0.001$ ), high calcium-phosphate product (OR 1.43, IC 95\% 1.01-2.03, $p=0.040$ ) and iron deficiency (OR 1.95, IC 95\% 1.38-2.75, $p=0.001$ ). Glomerulopathies (OR 0.44, IC 95\% 0.22-0.90, $p=0.026$ ), female gender (OR 0.55 , IC 95\% 0.40-0.074, $\mathrm{p}=0.001$ ) and erythropoietin administration (OR 0.57, IC $95 \%$ 0.39-0.82, $\mathrm{p}=0.002$ ) were associated with hemoglobin $\geq 10 \mathrm{~g} / \mathrm{dl}$.
\end{abstract}

Conclusion: The factors associated with $\mathrm{Hb}<10.0 \mathrm{~g} / \mathrm{dl}$ were mineral-bone metabolism disorders and iron deficiency. The periodic evaluation of qualityof-care indicators of HD treatment, such anemia, are necessary to detect improvement opportunities.

Keywords: Anemia; Hemodialysis; Associated factors

\section{Background}

Anemia is one of the earliest and most frequent manifestations of Chronic Kidney Disease (CKD).

$\mathrm{CKD}$ anemia is of multifactorial origin [1,2]. However, the immediate cause is the inadequate production of endogenous Erythropoietin (EPO) due to atrophy or injury to the renal peritubular cells responsible for its synthesis that, consequently, decreases the production of erythrocytes, promotes the apoptosis of erythroid progenitors and lessens the proliferation and differentiation of proerythroblasts and normoblasts [3]. Iron is another important factor related to the development of anemia; iron deficiency in CKD is frequent and reduces the synthesis of hemoglobin. Iron deficiency is a consequence of insufficient intestinal absorption associated to a chronic inflammatory state. On the other hand, gastrointestinal losses and during Hemodialysis (HD) can contribute significantly [4].

The factors involved in CKD anemia includehyperparathyroidism, a complication secondary to phosphorus retention that decreases the response to EPO [3-6]. The deficiency of folates or vitamin B12 also contributes to the development of anemia, specifically the macrocytic type, which has a frequency of $5 \%$ approximately, a proportion that may be higher in patients in HD, suggesting loss of vitamin B12 and folic acid during the HD [7].
The Angiotensin-Converting Enzyme Inhibitors (ACEI) and the Angiotensin Receptor Blockers (ARB) often employed in patients with CKD, participate in the production of anemia by inhibiting the erythropoietic effects of angiotensin II, in addition to reducing the EPO synthesis by increasing the renal blood flow [8-10].

In $\mathrm{CKD}$, anemia is an independent risk factor to myocardial injury, it favours the development and progression of left ventricle hypertrophy and heart failure [11,12], additionally, increases the number of hospitalizations contributing to a declining quality of life and higher mortality $[1,13]$. Previous studies have shown that hemoglobin levels $<8 \mathrm{~g} / \mathrm{dl}$ and hematocrit $<30 \%$ are associated with twice the risk of death compared to patients with hemoglobin between $10-11 \mathrm{~g} / \mathrm{dl}$ and hematocrit among 33-36\%. [14,15].

On account of its high frequency, its impact on the patients' quality of life, and mainly because it is susceptible to intervention, the control of anemia is considered a quality-of-care indicator and has been included in international studies such as Dialysis Outcomes and Prescription Patterns Study (DOPPS) as an evaluation criteria, establishing the reference values that are associated with the best clinical outcome. Only developed countries participate in these studies, nevertheless its extension to developing countries is also highly important.

In Mexico's case, the utmost proportion of patients in HD are
Ann Hematol Oncol - Volume 8 Issue 1 - 2021 ISSN : 2375-7965 | www.austinpublishing group.com Hernández Rivera et al. (C) All rights are reserved
Citation: Lizardi Gómez LF, Reyes Sánchez I, Guerrero Soto J, Rivera Antolin JE, Muñoz Menjivar C, Venegas Vera AV, et al. Factors Related to the Presence of Anemia in Patients with Chronic Kidney Disease in Hemodialysis. Ann Hematol Oncol. 2021; 8(1): 1326. 
treated by a single social security institution, IMSS. This institution outsources HD to private organizations through specific contracts in which certain management criteria are established, including anemia control. However, regarding the patient management both HD providers and IMSS participate, the latter with specialized consultations and input supply (EPO, supplemental iron, hematology consultation and drugs related). The coordination of this joint responsibility is complex, therefore the information related to the control of anemia is insufficient.

Based on the forementioned, the goal of this study was to identify the frequency in which the optimal levels of hemoglobin and hematocrit are achieved and the factors associated to the presence of values lower than those recommended in a population of patients receiving subrogate HD (extramural) by the Mexican Institute of Social Security (IMSS).

\section{Materials and Methods}

Design: A cross-sectional study was conducted with the total current patients treated in HD units outsourced by IMSS in the northern metropolitan area of Mexico City by December 31, 2019.

Patients: We included adult patients with CKD diagnosis from any cause, with no upper age limit, of either gender, treated in subrogated HD units. We excluded patients with less than three HD sessions per week and patients with chronic or acute infectious diseases documented at the beginning of the HD program. Pregnant patients and patients with bleeding history within 3 months previous to the study, were also excluded. Patients who deceased or had bleeding episodes during the study period were eliminated.

Data collection: The last serum hemoglobin value documented at the HD unit from every patient by December 31, 2019 was registered. Patients were classified into two groups according to the levels of hemoglobin establishing as cutoff values less than $10 \mathrm{~g} / \mathrm{dl}$ (regarding the fulfilment of $\mathrm{Hb}$ goals in CKD patients) and patients without anemia for those with hemoglobin level $>10 \mathrm{~g} / \mathrm{dl}$. Mean corpuscular volume, serum iron, transferrin saturation percentage and ferritin were recorded for both groups, as well as PTH concentration, number of transfusions, treatment with ACEI o ARB, iron and EPO doses registered on the IMSS medical record.

Statistics: Data is presented as mean and standard deviation (and interquartile range) or as frequency according with the variable type and their distribution. Comparisons between groups were established with chi square and Student's t-test for variables with normal distribution, and Mann-Whitney $U$ for those of free distribution. Variables with differences between groups were, subsequently, included in the logistic regression multivariate analysis to identify risk factors for the presence of hemoglobin and hematocrit values $<10 \mathrm{~g} /$ dL y $33 \%$, respectively. The value of $\mathrm{p}-0.05$ was considered significant. The statistical package SPSS version 25 was employed.

\section{Results}

Study population characteristics. Nine hundred and five patients were eligible, of them, 110 patients fulfilled the exclusion criteria and 48 were eliminated, therefore 747 patients were considered for the analysis. The demographic and clinical data of the 747 patients are shown on (Table 1). The most frequent etiology for $\mathrm{CKD}$ was diabetes
Table 1: Baseline characteristics.

\begin{tabular}{|l|c|c|c|c|}
\hline \multicolumn{1}{|c|}{ Variable } & Mean & $( \pm)$ SD & Median & IQR 25-75 \\
\hline Age (years) & 50.61 & 15.64 & 51 & $37-63$ \\
\hline Weight (kilograms) & 66.36 & 15.24 & 65 & $56-75.5$ \\
\hline Height (meters) & 1.61 & 0.09 & 1.6 & $1.54-1.69$ \\
\hline BMI (kg/m²) & 25.47 & 4.97 & 24.57 & $22.05-28.22$ \\
\hline Hemoglobin (g/dL) & 9.7 & 1.83 & 9.7 & $8.4-10.9$ \\
\hline MCV (fl) & 92.29 & 8.19 & 92.8 & $87.97-97.90$ \\
\hline Calcium (mg/dL) & 8.37 & 1.13 & 8.4 & $7.7-9.0$ \\
\hline Phosphorus (mg/dL) & 5.16 & 2.03 & 4.9 & $3.7-6.32$ \\
\hline Calcium-phosphate product & 43.16 & 18.05 & 40.5 & $30.10-53.63$ \\
\hline Parathyroid hormone (pg/dL) & 643.57 & 668.9 & 467 & $121.5-922$ \\
\hline Serum iron (ug/dL) & 59.9 & 38.43 & 51 & $35-72$ \\
\hline Transferrin saturation (\%) & 25.29 & 21.04 & 19.96 & $12.24-30.61$ \\
\hline TIBC (mcg/dL) & 268.91 & 78.24 & 264.41 & $210.03-326.29$ \\
\hline Transferrin (mg/dL) & 215.27 & 62.42 & 211.5 & $211.5-261$ \\
\hline Ferritin (ng/dL) & 327.81 & 640.03 & 86 & $30-330.5$ \\
\hline IV iron dose (mg/week) & 238.7 & 304.32 & 100 & $100-300$ \\
\hline EPO dose (Ul/week) & 10097 & 4240.11 & 12000 & $8000-12000$ \\
\hline Number of transfusions & 1.82 & 0.99 & 2 & $1-2$ \\
\hline SD: Standard Deviaion; & & & & \\
\hline
\end{tabular}

SD: Standard Deviation; IQR: Interquartile Range; BMI: Body Mass Index; MCV: Mean Corpuscular Volume; TIBC: Total Iron-Binding Capacity; IV: Intravenous; EPO: Erythropoietin.

Table 2: Mean differences by group of study.

\begin{tabular}{|c|c|c|c|}
\hline $\begin{array}{c}\text { Variable } \\
\text { (Mean and } S D \pm)\end{array}$ & $\begin{array}{c}\text { Patients with } H b<10 \\
g / d L\end{array}$ & $\begin{array}{c}\text { Patients with } H b \geq 10 \\
g / d L\end{array}$ & $p$ \\
\hline Age (years) & 48.55 (15.37) & $52.27(15.52)$ & 0.001 \\
\hline Weight (kilograms) & $65.97(15.74)$ & $67.18(14.74)$ & 0.297 \\
\hline Height (meters) & $1.60(0.10)$ & $1.61(0.09)$ & 0.227 \\
\hline BMI $\left(\mathrm{kg} / \mathrm{m}^{2}\right)$ & $25.42(5.19)$ & $25.66(4.73)$ & 0.533 \\
\hline Hemoglobin (g/dl) & $8.41(1.08)$ & $11.34(1.15)$ & 0.001 \\
\hline $\operatorname{MCV}(\mathrm{fl})$ & $91.34(8.44)$ & $93.49(7.71)$ & 0.001 \\
\hline Calcium (mg/dl) & $8.31(1.14)$ & $8.44(1.11)$ & 0.12 \\
\hline Phosphorus (mg/dl) & $5.45(2.07)$ & $4.93(1.98)$ & 0.001 \\
\hline $\begin{array}{l}\text { Calcium-phosphate } \\
\text { product }\end{array}$ & $45.92(18.35)$ & 40.99 (17.53) & 0.001 \\
\hline $\begin{array}{l}\text { Parathyroid hormone } \\
\text { (pg/dl) }\end{array}$ & $649.22(759.49)$ & $636.19(557.13)$ & 0.902 \\
\hline Serum iron (ug/dl) & $56.22(39.53)$ & $64.58(36.51)$ & 0.004 \\
\hline $\begin{array}{l}\text { Transferrin saturation } \\
(\%)\end{array}$ & $24.62(22.43)$ & $26.16(19.13)$ & 0.331 \\
\hline TIBC (mcg/dl) & $265.44(84.04)$ & $273.33(70.06)$ & 0.18 \\
\hline Transferrin (mg/dl) & $212.71(66.94)$ & 218.53 (56.09) & 0.215 \\
\hline Ferritin (ng/dl) & $358.44(589.44)$ & $288.85(698.14)$ & 0.148 \\
\hline IV iron dose (mg/week) & $268.88(321.90)$ & 217.77 (295.64) & 0.435 \\
\hline EPO dose (UI/week) & $10656.62(4337.30)$ & 9421.73 (4101.28) & 0.001 \\
\hline Number of transfusions & $1.83(0.82)$ & $1.78(1.10)$ & 0.779 \\
\hline
\end{tabular}

mellitus (24.9\% of patients) and arterial hypertension (16.3\%). Primary glomerulopathies were the cause in $5.5 \%$ of patients and less than $5 \%$ were found to originate secondarily from other entities, such as preeclampsia, polycystic kidney disease and vesicoureteral 
Table 3: Bivariate analysis, anemia in HD patients. $(n=747)$.

\begin{tabular}{|c|c|c|c|}
\hline Variable & OR & $\mathrm{Cl} 95 \%$ & $p$ \\
\hline Male gender & 1.81 & $1.34-2.45$ & 0.001 \\
\hline Female gender & 0.55 & $0.40-0.74$ & 0.001 \\
\hline Diabetes mellitus & 1.49 & $1.06-2-10$ & 0.022 \\
\hline Arterial hypertension & 0.98 & $0.66-1.46$ & 0.94 \\
\hline Glomerulopathies & 0.44 & $0.22-0.90$ & 0.026 \\
\hline High mean corpuscular volume & 1.33 & $0.88-1.99$ & 0.165 \\
\hline Hypocalcemia (<8 mg/dl) & 0.77 & $0.56-1.05$ & 0.109 \\
\hline Hypercalcemia (>10 mg/dl) & 1.54 & $0.78-3.05$ & 0.212 \\
\hline Hypophosphatemia (<2.5 mg/dl) & 0.44 & $0.23-0.83$ & 0.012 \\
\hline Hyperphosphatemia (>4.5 mg/dl) & 1.69 & $1.21-2.28$ & 0.001 \\
\hline Calcium-phosphate product $\left(>55 \mathrm{mg}^{2} / \mathrm{dl}^{2}\right)$ & 1.43 & $1.01-2.03$ & 0.04 \\
\hline Hyperparathyroidism (PTH >300 pg/dl) & 1.59 & $0.81-3.01$ & 0.153 \\
\hline $\begin{array}{l}\text { Iron deficiency (transferrin saturation }<20 \% \text {, ferritin } \\
<500 \mathrm{ng} / \mathrm{dl} \text { ) }\end{array}$ & 1.95 & $1.38-2.75$ & 0.001 \\
\hline $\begin{array}{l}\text { Absolute iron deficiency (transferrin saturation } \\
<20 \% \text {, ferritin }<200 \mathrm{ng} / \mathrm{dl} \text { ) }\end{array}$ & 1.96 & $1.41-2.72$ & 0.001 \\
\hline $\begin{array}{l}\text { Functional iron deficiency (transferrin saturation } \\
<20 \% \text {, ferritin } 200 \text { a } 500 \mathrm{ng} / \mathrm{dl} \text { ) }\end{array}$ & 0.72 & $0.34-1.55$ & 0.41 \\
\hline $\begin{array}{l}\text { Iron overload (transferrin saturation }>45 \% \text {, ferritin } \\
>1000 \mathrm{ng} / \mathrm{dl} \text { ) }\end{array}$ & 1.06 & $0.65-1.71$ & 0.807 \\
\hline Transferrin saturation $<20 \%$ & 0.74 & $\begin{array}{l}0.55- \\
1.001\end{array}$ & 0.051 \\
\hline Transferrin saturation $>45 \%$ & 1.06 & $0.65-1.71$ & 0.807 \\
\hline Serum TIBC <230 mcg/dl & 0.70 & $0.51-0.97$ & 0.032 \\
\hline Serum TIBC >380 mcg/dl & 0.58 & $0.25-1.38$ & 0.223 \\
\hline Serum transferrin $<170 \mathrm{mg} / \mathrm{dl}$ & 0.65 & $0.46-0.92$ & 0.015 \\
\hline Serum transferrin $>380 \mathrm{mg} / \mathrm{dl}$ & 1.27 & 0.17-9.09 & 0.809 \\
\hline Serum ferritin <200 ng/dl & 1.96 & $1.41-2.72$ & 0.001 \\
\hline Serum ferritin $>500 \mathrm{ng} / \mathrm{dl}$ & 0.53 & $0.35-0.79$ & 0.002 \\
\hline ACEI intake & 0.54 & $0.27-1.10$ & 0.091 \\
\hline ARB intake & 1.03 & $0.76-1.39$ & 0.84 \\
\hline B-complex vitamin intake & 1.06 & $0.76-1.48$ & 0.696 \\
\hline Folic acid intake & 1.10 & $0.78-1.54$ & 0.572 \\
\hline Oral iron intake & 1.11 & $0.82-1.50$ & 0.471 \\
\hline IV iron administration & 1.31 & $0.84-2.05$ & 0.222 \\
\hline EPO administration & 0.57 & $0.39-0.82$ & 0.002 \\
\hline Transfusion history & 0.73 & $0.50-1.07$ & 0.113 \\
\hline
\end{tabular}

reflux, while forty-eight percent of patients did not have a determined etiology.

Consistent with the WHO definition of anemia and the KDIGO guidelines $(<13 \mathrm{~g} / \mathrm{dl}$ in men and $<12 \mathrm{~g} / \mathrm{dl}$ in women), $94.2 \%$ of the patients had anemia $(n=676)$. For the purpose of this study, anemia was defined as $\mathrm{Hb}<10 \mathrm{~g} / \mathrm{dl}$, which was found in $56 \%$ of the patients $(\mathrm{n}=402)$. The mean level of hemoglobin was $9.7 \mathrm{~g} / \mathrm{dl}$, with a median of $9.7 \mathrm{~g} / \mathrm{dl}$ (IQR $8.4-10.9 \mathrm{~g} / \mathrm{dl}$ ). The mean corpuscular volume mean was $92.29 \pm 8.19 \mathrm{fl}$, median of $92.8 \mathrm{fl}$ (IQR 87.97 - $97.90 \mathrm{fl}$ ) (Table 1).

When the group was classified according to the cutoff value of $\mathrm{Hb}$ $<10 \mathrm{~g} / \mathrm{dl}$ (Table 2), 402 patients (53.8\%) were below this limit and 345 (46.2\%) above it. Patients with lower hemoglobin levels were older,
Table 4: Multivariate analysis. Anemia in HD patients $(n=747)$.

\begin{tabular}{|l|c|c|c|}
\hline \multicolumn{1}{|c|}{ Variable } & OR & Cl 95\% & $p$ \\
\hline Male gender & 1.62 & $1.17-2.25$ & $\mathbf{0 . 0 0 3}$ \\
\hline Female gender & 0.65 & $0.47-0.90$ & $\mathbf{0 . 0 1 0}$ \\
\hline Diabetes mellitus & 1.53 & $1.06-2.22$ & $\mathbf{0 . 0 2 2}$ \\
\hline Glomerulopathies & 0.67 & $0.32-1.42$ & 0.305 \\
\hline Hypophosphatemia & 0.55 & $0.27-1.10$ & 0.096 \\
\hline Hyperphosphatemia & 1.25 & $0.86-1.83$ & 0.229 \\
\hline Calcium-phosphate product $>55 \mathrm{mg}^{2} / \mathrm{dl}^{2}$ & 1.20 & $0.79-1.82$ & 0.388 \\
\hline Iron deficiency & 2.36 & $0.91-6.13$ & 0.076 \\
\hline Absolute iron deficiency & 1.18 & $0.51-2.71$ & 0.689 \\
\hline Serum transferrin $<170 \mathrm{mg} / \mathrm{dl}$ & 0.88 & $0.47-1.66$ & 0.712 \\
\hline Serum transferrin $<200 \mathrm{ng} / \mathrm{dl}$ & 1.93 & $1.25-2.98$ & $\mathbf{0 . 0 0 3}$ \\
\hline Serum ferritin $>500 \mathrm{ng} / \mathrm{dl}$ & 1.12 & $0.59-2.12$ & 0.726 \\
\hline Erythropoietin administration & 0.65 & $0.44-0.95$ & $\mathbf{0 . 0 2 8}$ \\
\hline
\end{tabular}

with higher phosphorus, lower iron and superior EPO requirements.

In the bivariate analysis (Table 3), male gender, diabetes, hyperphosphatemia, higher calcium-phosphate product and iron deficiency were risk factors for $\mathrm{Hb}$ under the cutoff limit. Female gender, glomerulopathies, hypophosphatemia, serum ferritin $>500$ $\mathrm{ng} / \mathrm{dl}$ and EPO administration were found to be protective factors.

Variables proved to be significant in the univariate analysis were included in the multivariate analysis, this information is shown in (Table 4). Male gender, diabetes and serum ferritin <200ng/dl were independent risk factors for $\mathrm{Hb}$ below $10 \mathrm{~g} / \mathrm{dl}$. Female gender and $\mathrm{EPO}$ administration remained as protective factors.

\section{Discussion}

The results in this study show a higher frequency of $\mathrm{Hb}$ below the recommended value in patients receiving HD at IMSS. Male gender, diabetes and iron deficiency assessed by the serum ferritin levels were the independent risk factors for $\mathrm{Hb}$ below the cutoff value.

Anemia is a significant risk factor for cardiovascular comorbidity and cognitive impairment with repercussions on the quality of life [11-20]. For these reasons, it is considered an indicator to optimize treatment and reduce the complications associated with HD. Studies in other populations have acknowledge the presence of anemia in more than $70 \%$ of Stage 5 CKD patients [21]. In our study, we found that $94.2 \%$ of the patients have anemia according to the definition established by the KDIGO and the WHO. On the other hand, when analyzing the proportion of patients with hemoglobin levels $<10$ $\mathrm{g} / \mathrm{dl}$, as anemia was defined in our study, we identify that $56 \%$ of the patients do not meet the hemoglobin target according to the KDIGO guideline recommendations [22]. The GCC-DOPPS (Gulf Cooperation Council - Dialysis Outcomes and Practices Patterns Study) which included 927 patients in HD, reported mean values of $\mathrm{Hb}$ in $10.9 \mathrm{~g} / \mathrm{dl}$, ferritin $390 \mathrm{ng} / \mathrm{dl}$, transferrin saturation $28.4 \%$ and EPO dose of 8667 UI per week [23]. In our population, the average level of $\mathrm{Hb}$ was lower $(9.7 \mathrm{~g} / \mathrm{dl})$, as were the iron-status indicators (ferritin $327 \mathrm{ng} / \mathrm{dl}$, transferrin saturation 25.29\%), and higher doses of EPO were used per week (10 097 UI). Regarding the anemia 
management, the GCC-DOPPS reported broader prescription of Erythropoiesis Stimulating Agents (ESA), 88 vs. 78.8\%; higher IV iron dose, $53 \%$ vs. $12.4 \%$; and lower oral iron use $20 \%$ vs. $56.8 \%$ with respect to our population.

In this study, Diabetes Mellitus (DM) is recognized as a risk factor for $\mathrm{Hb}$ beneath the cutoff limit, a value that persisted through the multivariate analysis. Loutradis and cols [24] encountered a higher prevalence of anemia in diabetic patients $(47.8 \% v s .33 .2 \%, \mathrm{p}=0.004)$ and DM was an independent risk factor for the development of anemia in a study with 368 CKD patients: 184 with DM and 184 without DM (OR 2.20, CI 95\% 1.19-4.06).

In the DOPPS work conducted with patients in $\mathrm{HD}$, it was found that the probability of attaining $\mathrm{Hb}$ level $\geq 11 \mathrm{~g} / \mathrm{dl}$ was associated with mineral metabolism. For every $1 \mathrm{mg} / \mathrm{dl}$ rise in serum calcium the OR was 1.32 , CI $95 \% 1.25-1.40, \mathrm{p}=0.0001$, for phosphorus OR 1.08, CI 95\%, 1.05-1.11, p=0.0001, while each $100 \mathrm{pg} / \mathrm{ml}$ increment in $\mathrm{PTH}$ concentration had a protective factor OR 0.96, Ci 95\% 0.95-0.98, $\mathrm{p}=0.0001$ [25]. An inverse association was found in a more recent study performed by Boronat and cols with Stage 4 and 5 CKD patients [26]. For each $1 \mathrm{mg} / \mathrm{dl}$ rise in calcium levels the OR was 0.29, CI 95\% $0.16-0.49, p=0.0001$, and the presence of anemia was greater with the increasing phosphorus. For each $1 \mathrm{mg} / \mathrm{dl}$ increase in phosphorus the OR was 2.19, CI 95\% 1.55-3.15, p=0.001. In our study, serum phosphorus $>4.5 \mathrm{mg} / \mathrm{dl}$ (OR 1.69, CI 95\% 1.21-2.28, $\mathrm{p}=0.001$ ) and calcium phosphate product $>55 \mathrm{mg} 2 / \mathrm{dl} 2$ (OR 1.43 , CI $95 \% 1.01$ 2.03, $\mathrm{p}=0.04$ ) were recognized as risk factors for Hb below the cutoff value and serum phosphorus $<2.5 \mathrm{mg} / \mathrm{dl}$ was the only protective factor (OR 0.44, CI 95\% 0.23-0.83, p=0.012). Unlike the commented studies, ours could not establish an association between anemia and hyperparathyroidism (OR 1.59, CI 95\% 0.81-3.01, p=0.153); nevertheless, it is important to indicate that PTH concentration levels were only available in $22 \%$ of patients.

Iron deficiency anemia is a common complication for CKD patients and has been identified as a cause for ESA resistance [27]. We found iron deficiency (OR 1.95, CI 95\% 1.38-2.75, p=0.001) as a risk factor for $\mathrm{Hb}$ below the cutoff value. Analyzing the iron status abnormalities in an individual manner, ferritin $<200 \mathrm{ng} / \mathrm{dl}$ was recognized as a risk factor (OR 1.96, CI 95\% 1.41-2.72, $\mathrm{p}=0.001$ ) and levels greater than $500 \mathrm{ng} / \mathrm{dl}$ (OR 0.53, CI 95\% 0.35-0.79, p=0.002) were considered a protective factor, findings consistent with the current recommendations for iron supplementation in the KDIGO guidelines [22].

A systematic review and meta-analysis performed by Shepshelovich and cols. [28] which included 2369 patients with CKD in stages 3-5 and 818 patients with stage 5 CKD in dialysis treatment (5D) showed the superiority of IV iron use compared to oral iron supplementation to increase hemoglobin levels $1 \mathrm{~g} / \mathrm{dl}$ (RR 1.61, CI 95\% 1.39-1.87 for CKD 3-5 and RR 2.12, CI 1.68-2,72 for CKD 5D) according to actual recommendations. In our study, $72.1 \%$ of patients had iron deficiency and just $12.4 \%$ were managed with IV iron, while $56.8 \%$ of patients received treatment with oral supplements. We did not find the variables related to iron metabolism as risk factors for $\mathrm{Hb}$ beneath the cutoff value.

The employment of ESA in the management of anemia in CKD patients increases the levels of $\mathrm{Hb}$, diminishes transfusion requirements and decreases morbidity and mortality [29-33]. In our study, the EPO administration was considered a protective factor for $\mathrm{Hb}$ below the cutoff limit with an OR 0.57 (CI 95\% 0.39-0.82, $\mathrm{p}=0.002$ ) in the bivariate analysis and it remained as an independent factor after the multivariate analysis (OR 0.65, CI 95\% 0.44-0.95, $\mathrm{p}=0.028$ ).

In the studied population, we identified that $7.8 \%$ of the total patients with anemia were macrocytic anemias; however, a limitation of our results is we did not have routine determinations of folate or vitamin B12 levels. In other studies, macrocytic anemia due to folate or vitamin B12 deficiency is around 5\% [7]. No benefit was found with folic acid administration (OR 1.10, CI 95\% 0.78-1.54, $\mathrm{p}=0.572$ ) or B-complex vitamins (OR 1.06, CI 95\% 0.76-1.48, $\mathrm{p}=0.696$ ).

Prescription of ACEI and ARB has been associated with anemia in CKD. A meta-analysis from Cheungpasitporn and cols [10] reported a RR of 1.57 (CI 95\% 1.40-1.73, I2=17\%) for ACEI and a RR of 1.58 (CI 95\%, 1.38-1.83, I2=0\%) for ARB use [13]. In our study, ACEI (OR 0.54, CI 95\% 0.27-1.10, p=0.091) nor ARB (OR 1.03, CI $95 \%$ 0.76-1.39, $\mathrm{p}=0.84$ ) were recognized as risk factors for $\mathrm{Hb}$ under the cutoff limit.

It has been previously described that women have lower levels of $\mathrm{Hb}$ and hematocrit than men. Physiological differences between genders participate in this variation. Considering different cutoff values to define anemia in each gender, the lower $\mathrm{Hb}$ levels in women are inferior to those in men at all CKD stages [34]. In this study we also encountered differences regarding a lower mean $\mathrm{Hb}$ in women (9.29 $v s .10 .01 \mathrm{~g} / \mathrm{dl}$ ); despite this, after conducting the multivariate analysis, the female gender was found to be a protective factor (OR 0.65, CI $95 \%$ 0.47-0-90, $\mathrm{p}=0.010$ ) and, consequently, male gender a risk factor (OR 1.62, CI 95\% 1.17-2.25, $\mathrm{p}=0.003$ ) attributed to a better iron status and less mineral-bone metabolism disturbances in women.

Being retrospective, the study has several limitations, essentially due to the unavailability of laboratory tests of variables with known effect over the presence and severity of anemia such as PTH, vitamin $\mathrm{B} 12$ and folate values.

\section{Conclusions}

The prevalence of anemia in CKD patients receiving $\mathrm{HD}$ treatment at our setting is higher than what has been found in other populations. The modifiable causes associated to a lower concentration of $\mathrm{Hb}$ were disturbances in mineral-bone metabolism such as hyperphosphatemia and high calcium-phosphate product, as well as abnormalities in the variables related to iron metabolism and reduced usage of EPO. Periodic studies such the one presented here are necessary to detect improvement opportunities in the quality of care to decrease morbidity and mortality in HD patients.

\section{Acknowledgments}

We thank Dr. Jesús Manolo Ramos Gordillo and Dr. Félix Mark Olvera Cartas for the facilities provided to obtain the data for this study. A special thanks to Dr. Vilma Adriana Ajiz Payán for her unconditional support during the development of the study, writing and editing of the manuscript.

\section{References}

1. Babitt JL, Lin HY. Mechanisms of anemia in CKD. J Am Soc Nephrol. 2012; 23: 1631-1634. 
2. El-Achkar TM, Ohmit SE, McCullough PA, Crook ED, Brown WW, Grimm R, et al. Higher prevalence of anemia with diabetes mellitus in moderate kidney insufficiency: The Kidney Early Evaluation Program. Kidney Int. 2005; 67 1483-1488.

3. Amador-Medina LF. Anemia en enfermedad renal crónica. Rev Med Inst Mex Seguro Soc. 2014; 52: 660-665

4. Cases A, Egocheaga MI, Tranchec S, Pallarésd V, Ojeda R, Górriza JL, et al. Anemia en la enfermedad renal crónica: protocolo de estudio, manejo y derivación a Nefrología. Nefrología. 2018; 38: 8-12.

5. Kalantar-Zadeh K, Lee GH, Miller JE, Streja E, Jing J, Robertson JA, et al. Predictors of hyporesponsiveness to erythropoiesis-stimulating agents in hemodialysis patients. Am J Kidney Dis. 2009; 53: 823-834.

6. Gaweda AE, Goldsmith LJ, Brier ME, Aronoff GR. Iron, inflammation, dialysis adequacy, nutritional status, and hyperparathyroidism modify erythropoietic response. Clin J Am Soc Nephrol. 2010; 5: 576-581.

7. Afshar R, Sanavi S, Salimi J, Ahmadzadeh M. Hematological profile of Chronic Kidney Disease (CKD) patients in Iran, in pre-dialysis stages and after initiation of hemodialysis. Saudi J Kidney Dis Transpl. 2010; 21: 368 371

8. Mohanram A, Zhang Z, Shahinfar S, Lyle PA, Toto RD. The effect of losartan on hemoglobin concentration and renal outcome in diabetic nephropathy of type 2 diabetes. Kidney Int. 2008; 73: 630-636

9. Plata R, Cornejo A, Arratia C, Anabaya A, Perna A, Dimitrov BD, et al. Angiotensin-converting-enzyme inhibition therapy in altitude polycythaemia: a prospective randomized trial. Lancet. 2002; 359: 663-666.

10. Cheungpasitporn W, Thongprayoon C, Chiasakul T, Korpaisarn S, Erickson SB. Renin-angiotensin system inhibitors linked to anemia: a systematic review and meta-analysis. QJM. 2015; 108: 879-884.

11. Drueke TB, Locatelli F, Clyne N, Eckardt KU, Macdougall IC, Tsakiris D, et al. Normalization of hemoglobin level in patients with chronic kidney disease and anemia. N Engl J Med. 2006; 355: 2071-2084.

12. Foley RN, Parfrey PS, Harnett JD, Kent GM, Murray DC, Barre PE. The impact of anemia on cardiomyopathy, morbidity, and mortality in end-stage renal disease. Am J Kidney Dis. 1996; 28: 53-61.

13. Mikhail A, Brown C, William JA, Mathrani V, Shrivastava R, Evans J, et al. Renal association clinical practice guideline on Anaemia of Chronic Kidney Disease. BMC Nephrol. 2017; 18: 345.

14. Madore F, Lowrie EG, Brugnara C, Lew NL, Lazarus JM, Bridges $\mathrm{K}$, et al. Anemia in hemodialysis patients: variables affecting this outcome predictor. $J$ Am Soc Nephrol. 1997; 8: 1921-1929.

15. Ma JZ, Ebben J, Xia H, Collins AJ. Hematocrit level and associated mortality in hemodialysis patients. J Am Nephrol. 1999; 10: 610-619.

16. London GM. Left ventricular alterations and end-stage renal disease. Nephrol Dial Transplant. 2002; 17: 29-36.

17. Martínez-Vea A, Marcas L, Bardají A, Romeu M, Gutierrez C, García C, et al. Role of oxidative stress in cardiovascular effects of anemia treatmen with erythropoietin in predialysis patients with chronic kidney disease. Clin Nephrol. 2012; 77: 171-181.

18. Go AS, Chertow GM, Fan D, McCulloch CE, Hsu CY. Chronic kidney disease and the risks of death, cardiovascular events, and hospitalization. N Engl J Med. 2004; 351: 1296-1305.

19. Silverberg DS, Wexler D, Blum M, Sheps D, Schwartz D, Yachnin T, et al. Aggressive therapy of congestive heart failure and associated chronic renal failure with medications and correction of anemia stops or slows the progression of both diseases. Perit Dial Int. 2001; 21: 236-240.
20. Silverberg DS, Wexler D, Blum M, Tchebiner JZ, Sheps D, Keren G, et al The effect of correction of anaemia in diabetics and non-diabetics with severe resistant congestive heart failure and chronic renal failure by subcutaneous erythropoietin and intravenous iron. Nephrol Dial Transplant. 2003; 18: 141146

21. Hsu CY, McCulloch CE, Curhan GC. Epidemiology of anemia associated with chronic renal insufficiency among adults in the United States: results from the Third National Health and Nutrition Examination Survey. J Am Soc Nephrol. 2002; 13: 504-510.

22. Kidney Disease: Improving Global Outcomes (KDIGO) Anemia Work Group KDIGO Clinical Practice Guideline for Anemia in Chronic Kidney Disease. Kidney Int Suppl. 2012; 2: 279-335.

23. Abouchacra S, Obaidli A, Al-Ghamdi S, Al Wakeel J, Al Salmi I, et al, GCC DOPPS 5 Study Group. Gulf Cooperation Council-Dialysis Outcomes and Practice Patterns Study: An Overview of Anemia Management Trends at the Regional and Country Specific Levels in the Gulf Cooperation Council Countries. Saudi J Kidney Dis Transpl. 2016; 27: S51-S61.

24. Loutradis C, Skodra A, Georgianos P, Tolika P, Alexandrou D, Avdelidou A et al. Diabetes mellitus increases the prevalence of anemia in patients with chronic kidney disease: A nested case-control study. World J Nephrol. 2016; 5: $358-366$

25. Kimata N, Akiba T, Pisoni RL, Albert JM, Satayathum S, Cruz JM, et al. Mineral metabolism and haemoglobin concentration among haemodialysis patients in the Dialysis Outcomes and Practices Patterns Study (DOPPS). Nephrol Dial Transplant. 2005; 20: 927-935.

26. Boronat M, Santana Á, Bosch E, Lorenzo D, Riaño M, García-Cantón C Relationship between anemia and serum concentrations of calcium and phosphorus in advanced non-dialysis dependent chronic kidney disease. Nephron. 2017; 135: 97-104.

27. Vaziri ND. Safety issues in iron treatment in CKD. Semin Nephrol. 2016; 36 : 112-118.

28. Shepshelovich D, Rozen-Zvi B, Avni T, Gafter U, Gafter-Gvili A. Intravenous versus oral iron supplementation for the treatment of anemia in CKD: An updated systematic review and meta-analysis. Am J Kidney Dis. 2016; 68: 677-690

29. Winearls CG, Oliver DO, Pippard MJ, Reid C, Downing MR, Cotes PM. Effect of human erythropoietin derived from recombinant DNA on the anaemia of patients maintained by chronic haemodialysis. Lancet. 1986; 2: 1175-1178.

30. Eschbach JW, Egrie JC, Downing MR, Browne JK, Adamson JW. Correction of the anemia of end-stage renal disease with recombinant human erythropoietin: results of a combined phase I and II clinical trial. N Engl J Med. 1987; 316: 73-78

31. Eschbach JW, Abdulhadi MH, Browne, JK. Recombinant human erythropoietin in anemic patients with end-stage renal disease: results of a phase III multicenter clinical trial. Ann Intern Med. 1989; 111: 992-1000.

32. Macdougall IC, Lewis NP, Saunders MJ. Long-term cardiorespiratory effects of amelioration of renal anaemia by erythropoietin. Lancet. 1990; 335: 489493.

33. Winearls CG. Historical review on the use of recombinant human erythropoietin in chronic renal failure. Nephrol Dial Transplant. 1995; 10: 3-9.

34. Cobo G, Hecking M, Port FK, Exner I, Lindholm B, Stenvinkel P, et al. Sex and gender differences in chronic kidney disease: progression to end-stage renal disease and haemodialysis. Clin Sci. 2016: 130: 1147-1163. 